\title{
Study on the Use of Agricultural Wastes for Cellulase Production by Using Aspergillus Niger
}

\author{
Jadhav A. R.*, Chitanand M. P., Shete H. G. \\ * Post Graduate Department of Microbiology, N. S. B. College Nanded (M.S.) India
}

\begin{abstract}
It was the goal to investigate the Cellulase enzyme production ability of fungal strains such as Aspergillus niger against the lignocellulosic bio-waste like Rice husks, Millet husks, Maize cobs, Wheat straws and leaves at varying environmental parameters of $\mathrm{pH}$, substrate concentration and dry weight and wet weight. The enzyme production was analyzed individually by Miller's modified method of Dinitrosalicylic acid ( DNSA ). In this study the high level of enzyme production was achieved at $\mathrm{pH} 3$ by using Rice husks, Millet husks, Maize cobs, Wheat straws and leaves and $\mathrm{pH} 4$ by using Maize cobs at varying substrate concentrations. Out of all the five used substrates rice husks gave the higher production of the cellulose enzyme. The importance of cellulase enzyme in industries cannot be over emphasized.
\end{abstract}

Key words: Cellulase, Agricultural waste, Aspergillus niger.

\section{Introduction :}

Agricultural and industrial wastes are among the causes of environmental pollution. Their conversion into useful products may ameliorate the problems they cause. These wastes which includes mainly leaves, straws, cereals, corncobs etc., in many countries, these materials are generally used as animal feeds. A huge amount of these materials are left on farmlands to be decomposed by microorganisms such as Bacteria and fungi.Cellulose is commonly degraded by an enzyme called cellulase. This is produced by several microorganisms, commonly by bacteria and fungi (Shin et. al., 2000; Immanuel et. al., 2006 ). Fungi are the main cellulase producing microorganisms, though a few bacteria and actinomycetes have also been reported to yield cellulase activity. For complete hydrolysis of cellulose to glucose, cellulase systems must contain endo -1, $4 \beta$-glucan ( 1, $4 \beta$ - D- glucanohydrolase' EC 3.2.1.4), exo -1, $4 \beta$-glucan ( 1, $4 \beta$ - D -cellobiohydrolase' EC 3.2.1.9) and $\beta$-glucosidase ( $\beta$ - D - glucohydrolase' EC 3.2.1.91) or cellobiase. Thus the hydrolysis of cellulose is completed by the synergistic action of endo- and exoglucanases. ( M. Fadel, 2000 ).

Effective conversion of recalcitrant lignocellulose to fermentable sugars requires three sequential steps: (1) size reduction, (2) pretreatment or fractionation and (3) enzymatic hydrolysis ( Zhang and Lynd, 2004; Wyman, 1999 ). One of the most important and difficult technological challenge is to overcome the recalcitrance of neutral lignocellulosic materials, which must be enzymatically hydrolyzed to produce fermentable sugars ( Demain et. al., 2005; Wyman, 1999 ).

\section{Isolation of Cellulolytic Fungi :-}

\section{Materials and Methods:}

The soil samples were aseptically collected from the agricultural area. Collected samples were sprinkled over sterile Potato dextrose agar plates. The plates were incubated for a period of 5 days at $30^{\circ} \mathrm{C}$. The growth of fungal colonies was observed after incubation period. The individual colonies were isolated and restreaked on the same agar plates. The cultures were observed under microscope to indentify the specific species based on some microscopic characteristics and morphological characteristics. ( M. A. Milala, 2005; G. Immanuel et. al., 2009 )

\section{Pre-treatment of substrate :-}

Raw substrates were sun dried individually to reduce the moisture content to make them more susceptible for crushing. The crushed substrates were then sieved individually to get powdered form. Then substrates were soaked individually in 1\% Sodium Hydroxide solution, in ratio 1:10 ( substrate : solution ) for 2 hours at room temperature. After which they were washed with distilled water to remove the unwanted chemicals. After washing distilled water was added in ratio $1: 10$ and autoclaved at $121^{\circ} \mathrm{C}$ for 1 hour. The treated substrates were then filtered and washed with distilled water until the wash water become neutral. ( Gharpuray et. al., 1999 ).

\section{Inoculum preparation :-}

The isolated cultures of Aspergillus niger were maintained as stock culture on Potato dextrose agar slants. They were grown at $30^{\circ} \mathrm{C}$ for 5 days and then stored at $4^{\circ} \mathrm{C}$ for regular sub culturing. $50 \mathrm{ml}$ of inoculum 
was prepared using potato dextrose broth in $250 \mathrm{ml}$ conical flask. The inoculum was kept in shaker ( $200 \mathrm{rpm}$ ) at $30^{\circ} \mathrm{C}$ for 24 hours before it was used for the fermentation process.

\section{Fermentation process :-}

Freshly prepared inoculums of Aspergillus niger was inoculated into $100 \mathrm{ml}$ of optimized culture medium ( L-glutamic acid $0.03 \mathrm{gm}, \mathrm{NH}_{4} \mathrm{NO}_{3} 0.14 \mathrm{gm}, \mathrm{KH}_{2} \mathrm{PO}_{4} 0.2 \mathrm{gm}, \mathrm{CaCl}_{2} 0.03 \mathrm{gm}, \mathrm{MgSO}_{4} 0.03 \mathrm{gm}$, Protease peptone $0.75 \mathrm{gm}, \mathrm{FeSO}_{4} 0.50 \mathrm{gm}, \mathrm{MnSO}_{4} 0.16 \mathrm{gm}, \mathrm{ZnSO}_{4} 0.14 \mathrm{gm}$, Tween 80 20\%, Substrate $3 \mathrm{gm}$, Distilled water $100 \mathrm{ml}$ ) having different substrates in separate $250 \mathrm{ml}$ Conical flasks with reference flasks. All flasks were incubated at $30^{\circ} \mathrm{C}$ for 9 days ( 0 to 216 hours ). The Cellulase activity was measured at regular intervals.

\section{Determination of time course for Cellulase production :-}

For determination of time course for cellulase production was carried out by measuring cellulase activity at regular intervals of 24 hours up to 216 hours.

\section{Determination of dry weight and wet weight :-}

After the completion of incubation period dry weight and wet weight was carried out.

\section{Determination of reducing sugar and Cellulase activity by Miller's modified method of DNSA:-}

The culture filtrate was collected from the fermentation media by centrifugation. $1 \mathrm{ml}$ of culture filtrate was taken in a test tube, $1 \mathrm{ml}$ of $1 \%$ cellulose solution and $1 \mathrm{ml}$ of distilled water was added into it. Control tube was made by adding $1 \mathrm{ml}$ of $1 \%$ cellulose solution and $2 \mathrm{ml}$ of distilled water. Allowed it to react for 30 minutes. Then $3 \mathrm{ml}$ of DNSA reagent was added in each test tube. The contents of test tubes were heated in boiling water bath for 5 minutes. After heating, contents were allowed to cool at room temperature. At the time of cooling, 7 $\mathrm{ml}$ of freshly prepared $40 \%$ Sodium Potassium Tartarate solution was added. After cooling, the samples were read at $540 \mathrm{~nm}$ by using Spectrophotometer. The amount of reducing sugar was determined by using standard graph. ( Miller GL, 1972 )

\section{Determination of Cellulase enzyme assay :-}

The cellulase enzyme was assayed by measuring the amount of glucose released from the substrates following the secretion of cellulase enzyme by the organism. The determination of glucose liberated from the substrate was done using the Miller's modified method of DNSA. 1 unit of cellulase activity was defined as the amount of enzyme which release 10 ug of glucose in the 30 minutes under specified conditions. ( M. A. Milala, 2005 ).

\section{Determination of effect of substrate concentration on cellulase production :-}

Different concentrations of the substrates ranging from $1 \%$ to $6 \%(\mathrm{w} / \mathrm{v})$ were added to the optimized culture medium in separate conical flasks. Inoculum medium of Aspergillus niger was inoculated into these fermentation media that is optimized culture medium and incubated at $30^{\circ} \mathrm{C}$ for 4 days ( 96 hours ). After incubation, enzyme activity was determined by Miller's Modified DNSA method.

\section{Determination of effect of $p H$ on cellulase production :-}

The optimized culture medium was prepared using the individual substrates with the $\mathrm{pH}$ varied from 3.0 to 8.0 ( $\mathrm{pH}$ was adjusted by adding $1 \mathrm{~N} \mathrm{NaOH}$ and $1 \mathrm{~N} \mathrm{HCl}$ ). Inoculum medium of Aspergillus niger was inoculated in these optimized culture medium and incubated at $30^{\circ} \mathrm{C}$ for 4 days ( 96 hours ). After incubation, enzyme activity was determined.

\section{Result And Discussion :-}

In the present work cellulose degrading fungi, indentified as Aspergillus niger was isolated from soil sample collected from agricultural area. The isolated fungi showed good ability to produce the cellulase enzyme.

Incubation period on cellulase production was determined. It was seen that rice husks gave the higher production that is 10.2 units / $\mathrm{ml}$ after 5 days of incubation. After that second highest production was obtained from Maize strips and wheat leaves and strips that are 9.9 unit / $\mathrm{ml}$ and 9.5 unit / $\mathrm{ml}$ respectively after 4 days. $8.65 \mathrm{unit} / \mathrm{ml}$ production was obtained from the Millet husks after 4 days. And the lowest production that is 5.3 unit / $\mathrm{ml}$ was obtained from the maize cobs after 6 days.

Substrate concentrations of $1 \%$ to $6 \%$ were considered. It was observed that wheat leaves and strips gave the higher production that is at $3 \%$ substrate concentration. After that second highest production was obtained from Millet husks, Maize strips and rice husks at $4 \%$ substrate concentration. And the lowest production was obtained from the maize cobs at $4 \%$ substrate concentration. The decrease in activity beyond maximum 
substrate concentration that is $5 \%$ may be due to the inhibitors. This is supported by the findings of Gbekeloluwa and Moo-young who reported the inhibitory effect of accumulated cellobiose and cellodextrin of low degree of polymerization. [ Gbekeloluwa B. O. et. al., 1991 ]

Effect of $\mathrm{pH}$ on cellulase production was determined. It was observed that millet husks, rice husks and wheat leaves \& strips gave the higher production at $\mathrm{pH} 3$. After that second highest production was obtained from Maize strips and maize cobs at pH 4. This is in agreement with the work of Ali et al 1991 in which pH of 3 and 4 reported as favouring higher yields of cellulase enzyme. [ Ali et. al., 1991 ]

The cellulase enzyme assay was determined by the determination of glucose molecule liberated from the substrate was done using the Miller's modified method of DNSA. 1 unit of cellulase activity was defined as the amount of enzyme which releases $10 \mathrm{ug}$ of glucose in the 30 minutes under specified conditions.

Observation Tables :

Table I :- Determination of dry weight and wet weight

\begin{tabular}{|c|c|c|c|c|c|}
\hline $\begin{array}{c}\text { Sr. } \\
\text { No. }\end{array}$ & Substrate & $\begin{array}{c}\text { Wt. of Whatmann's } \\
\text { filter paper in grams }\end{array}$ & $\begin{array}{c}\text { Wet weight in } \\
\text { grams }\end{array}$ & $\begin{array}{c}\text { Dry weight in } \\
\text { grams }\end{array}$ & $\begin{array}{c}\text { Wt. of Mycelium } \\
\text { in grams }\end{array}$ \\
\hline 1 & Rice Husks & 1.160 & 2.800 & 1.270 & $\mathbf{0 . 1 1 0}$ \\
\hline 2 & Millet Husks & 1.190 & 5.790 & 2.060 & $\mathbf{0 . 8 7 0}$ \\
\hline 3 & Wheat leaves \& Straws & 1.170 & 3.000 & 1.460 & $\mathbf{0 . 2 9 0}$ \\
\hline 4 & Maize Cobs & 1.180 & 3.160 & 1.410 & $\mathbf{0 . 2 3 0}$ \\
\hline 5 & Maize Strips & 1.170 & 3.752 & 1.360 & $\mathbf{0 . 1 9 0}$ \\
\hline
\end{tabular}

Figures:

Figure I : Determination of effect of incubation period on cellulase enzyme production
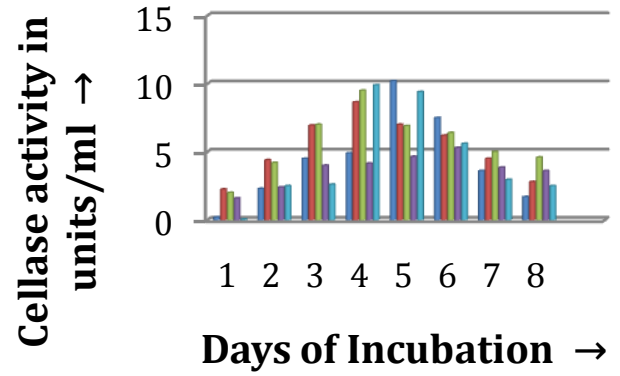

- Rice Husks

- Millet Husks

Wheat Leaves \&

Straws

Maize Cobs

Figure II : Determination of effect of substrate concentration on cellulase enzyme production.



Rice Husks

Wheat Leaves \& Straws

$\square$ Millet Husks

- Maize Cobs

- Maize Strips

Substrate concentration in $\% \rightarrow$ 
Figure III: Determination of effect of $\mathrm{pH}$ on cellulase enzyme production.

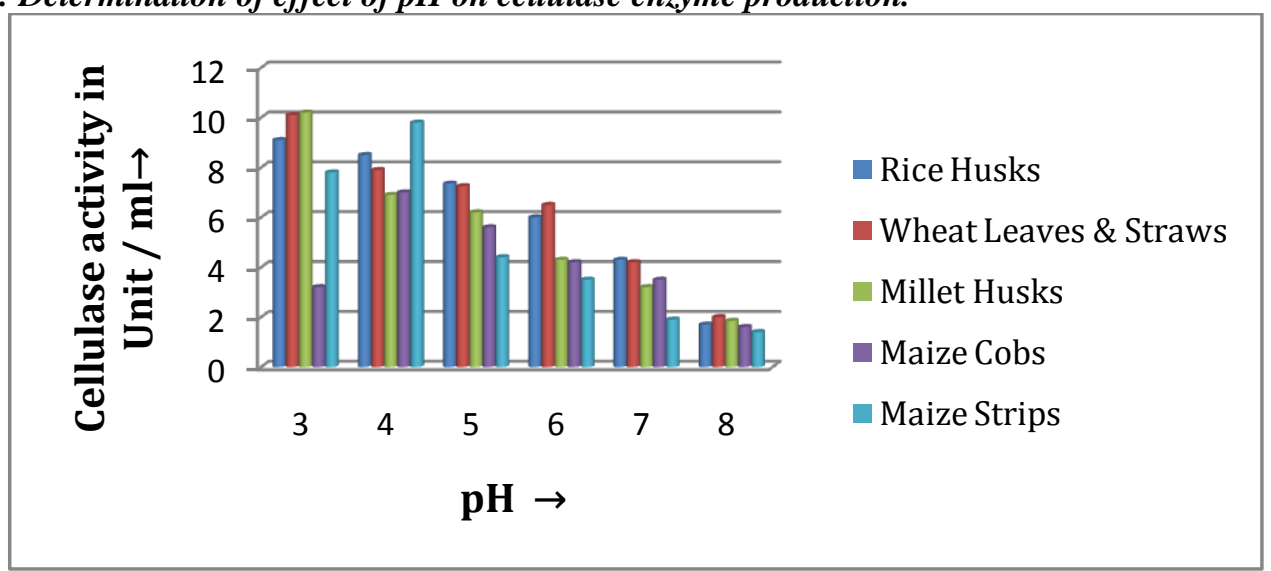

\section{Acknowledgements:}

We are thankful to the Principal, Netaji Subhashchandra Bose College Nanded for the support during the work

\section{References :-}

[1]. Ali S., Sayed A., Sarker R. T., and Alau R. (1991) factors affecting cellulase production by Aspergillus niger and Aspergillus terrus using water Hyacinth. World Journal of Microbial Biotechnology. 7: $62-66$.

[2]. Bayer E.A, Chanzy H., Lamed R. and Shoham Y. (1998): Cellulose, Cellulases and Cellulosomes, Curr Opin Struc Biol 8: 548 557

[3]. Demain A.L., Newcomb M. and J. H. D. Wu ( 2005 ) Cellulase, clostridia and ethanol. Microbiol. Mol. Bio. Rev., 69: 124 - 154.

[4]. Gharpuray M. M., Lee Y. H. and Fan L. T. ( 1983 ) Structural modification of lignocellulosic by treatment to enhance enzymatic hydrolysis. Biotechnol. 25: 157 - 170 .

[5]. Gbekeloluwa B. O. and Moo-young, ( 1991 ) Production and properties of \$-glucosidase by Neurospora sitophila. World Journal of Microbial Biotechnology. 7: 4-11.

[6]. Fadel M., ( 2000 ) Production physiology of Cellulase and $\beta$-glucosidase enzyme of Aspergillus niger grown under solid state fermentation conditions. Biological sciences 1 ( 5 ): $401-411$.

[7]. Immanuel G., Akila Bhagwat C. M., Iyappa Raj P., Esakkiraj P. and Palavesam A. ( 2009 ) Production and Partial purification of Cellulase by Aspergillus niger and A. fumigates fermented in coir waste and sawdust. International journal of Microbiology.

[8]. Milala M. A., Shugaba A., Gidado A., Ene A. C. and Wafar J. A., ( 2005 ) Studies on the use of agricultural wastes for cellulase enzyme production by Aspergillus niger. Research journal of Agri. And biology. Sciences 1(4): 325 -328.

[9]. Miller G.L. ( 1972 ) Use of Dinitrosalicylic acid reagent for determination of reducing sugar. Biotechnol. Bioeng. Symp. 5: 193 219

[10]. Pierre Beguin and Jean-Paul Aubert, ( 1994 ) The biological degradation of cellulose. FEMS Microbiology Reviews Volume 13, Issue 1, January 1994, Pages $25-58$

[11]. Shin C. S., Lee J. P., lee I. S. and Park S. C. ( 2000 ) Enzyme production of Trichoderma ressei. Rut C-30 on various lignocellulosic substrates. Appl. Biochem. Biotech. 84-86 ( 1-9): 237 - 245.

[12]. Wyman, ( 1999 ) C.E.: biomass Ethanol: Technical progress, opportunities, and commercial challenges. Annul. Rev. energy Environ., 24: 189 - 226

[13]. Zhang Y. H. P., and Lynd L. R., ( 2004 ) Toward an aggregated understanding of enzymatic hydrolysis of cellulose: Noncomplexed cellulase systems. Biotechnol. Bioeng., 89: 797 - 824.

[14]. Demain A. L, Newcomb M. and J. H. D. Wu ( 2005 ) Cellulase, clostridia and ethanol. Microbiol. Mol. Bio. Rev., 69: 124-154.

[15]. Gharpuray M. M., Lee Y. H. and Fan L. T. ( 1983 ) Structural modification of lignocellulosic by treatment to enhance enzymatic hydrolysis. Biotechnol. 25: 157-170.

[16]. Fadel M., ( 2000 ) Production physiology of Cellulase and $\beta$-glucosidase enzyme of Aspergillus niger grown under solid state fermentation conditions. Biological sciences 1 ( 5 ): 401-411.

[17]. Immanuel G., Akila Bhagwat C. M., Iyappa Raj P., Esakkiraj P. and Palavesam A. ( 2009 ) Production and Partial purification of Cellulase by Aspergillus niger and A. fumigates fermented in coir waste and sawdust. International journal of Microbiology.

[18]. Milala M. A., Shugaba A., Gidado A., Ene A. C. And Wafar J. A., ( 2005 ) Studies on the use of agricultural wastes for cellu lase enzyme production by Aspergillus niger. Research journol of Agri. And biolo. Sciences 1(4): 325-328.

[19]. Miller GL ( 1972 ) Use of Dinitrosalicylic acid reagent for determination of reducing sugar. Biotechnol. Bioeng. Symp. 5: 193-219

[20]. Shin C. S., Lee J. P., lee I. S. and Park S. C., ( 2000 ) Enzyme production of Trichoderma ressei. Rut C-30 on various lignocellulosic substrates. Appl. Biochem. Biotech. 84-86 ( 1-9): 237-245.

[21]. Wyman, ( 1999 ) C.E.: biomass Ethanol: Technical progress, opportunities, and commercial challenges. Annu. Rev. enrgy Environ., 24: $189-226$

[22]. Zhang Y. H. P. and Lynd L. R., ( 2004 ) Toward an aggregated understanding of enzymatic hydrolysis of cellulose: Noncomplexed cellulase systems. Bitechnol. Bioeng., 89: 797-824. 